\title{
活性污泥法における有機ハロゲン化合物前駆物質の挙動
}

\section{BEHAVIOR OF ORGANIC HALIDES PRECURSOR IN ACTIVATED SLUDGE PROCESS}

\author{
生方 悠*·相沢 貴子**・真柄泰 基*** \\ By Yuu UBUKATA, Takako AIZAWA and Yasumoto MAGARA
}

\begin{abstract}
In order to investigate the behavior of the organic halides precursor in the activated sludge process, bench scale reactors were operated at various organic loadings. Trihalomethane formation potential (THMFP) and total organic halides formation potential (TOXFP) were measured as the organic halides precursor. The effluent from the reactor fed by potato starch which has not THMFP produced THMs with the reaction of chlorine. In the experiments using primary settled municipal sewage or its 8 $\mu \mathrm{m}$ filtrate, the removal of THMFP was mainly associated with the removal of particulate precursor. THMFP of the effluent was related with a hard biodegrable organics in the influent and biological metabolic by-products. The ratio of THMFP/TOC of the effluent was increased than that of the influent, since the removal efficiency of THMFP was lower than that of TOC. TOXFP removal efficiency was almost the same as TOC removal efficiency.
\end{abstract}

\section{1.はじめに}

わが国の主要な都市が河川下流域に存在していること や, 水道原水を河川下流域で取水している浄水場が多い こともあって, これらの净水場の水道原水には上流域か ら排出される有機性廃水が不可避的に存在するように なっている. 一方, 水道の净水システムでは水道水の微 生物学的な安全性を確保するため塩素処理が行われてい るが, 原水中に天然のフミン質, 藻類あるいはし尿等が 存在すると塩素と反応してトリハロメタン（以下 THM とする) に代表される有機ハロゲン化合物が生成する.

有機ハロゲン化合物の中には変異原性や発癌性が明らか となっている物質もあり, 厚生省では水道水中の THM の暫定指針值を $100 \mu \mathrm{g} / l$ とし, WHO ではクロロホル ムについて $30 \mu \mathrm{g} / l$ というガイドラインを提示してい る. 発癌あるいは催奇形性という従来の衛生工学では 扱ってきたことがない健康影響を扱うものであるため, その工学的制御の方法には検討の余地があろう.しかし,

* 正会員 工修 都立大学助手 工学部土木工学科 ( ₹ 158 世田谷区深沢 2-1-1)

** 正会員 国立公衆衛生院主任研究官 衛生工学部 （空 108 港区白金台 4-6-1）

*** 正会員 工博 国立公衆衛生院部長 衛生工学部 (同上)
これらの指針値が示すように何らかの方法で水道水中の THM 等を制御しなければならないものと考える. それ には, 净水システムを補強して THM 等を生成しない ようにあるいは除去する方法と, 塩素と反応して THM 等を生成する物質（以下前駆物質とする）の水源水域へ の排出抑制を含めた水源管理がある. 本論文では, 後者 の水源管理に視点を置き, 特に下水処理に汎用されてい る活性污泥プロセスにおける前駆物質の挙動を扱い, 水 源水域に排出される前駆物質量やその活性污泥プロセス の維持管理により排出量が制御可能であるか否かを明ら かにすることとした．具体的には，澱粉を基質とする人 工下水および都市下水を用いたベンチスケール実験を 行った.なお, 下水処理場における前駆物質の挙動およ び除去, ならびに好気性消化プロセスにおける前駆物質 の挙動については山田ら ${ }^{1), 2)}$ の報告があるものの, 活性 污泥プロセスの維持管理指標と前駆物質生成量に関する 研究は, 曝気槽 $\mathrm{pH}$ および DO の影響を調べた Koczwara ${ }^{3)}$ らものがあるだけである.

\section{2. 実験方法}

\section{（1）人工下水を基質とする実験}

活性污泥法の処理効率を支配する 1 つの因子として活 性污泥の懸濁性有機物質吸着・凝集特性があり, またこ 
の吸着・凝集特性は活性污泥の有機物負荷上関係するこ とを真柄ら ${ }^{4)}$ は報告している．また，活性污泥微生物の 代謝排物は植物由来の天然フミン質と類似な構造をもつ 有機物であることを丹保ら ${ }^{5)}$ は報告している.

そこで，懸濁性であるが塩素と反応しても THM を 生成しない有機物として都市下水中に広く分布している と思われる澱粉を基質に選び，これを活性污泥微生物が 代謝する過程で前駆物質をどのように生成し，それが活 性污泥の吸着・凝集性とどのような関係にあるか明らか にすることとした．

活性污泥反応槽には Fig. 1 に示すような曝気槽容量 $350 \mathrm{~m} l$, 沈殿槽容量 $75 \mathrm{~m} l$ をもつガラス製のベンチス ケール装置を用いた．人工下水はバレイショ澱粉 400 $\mathrm{mg} / l$, 塩化アンモニウム $150 \mathrm{mg} / l$, リン酸一カリウム $224 \mathrm{mg} / l$, リン酸二カリウム $87 \mathrm{mg} / l$, リン酸二ナトリ ウム $458 \mathrm{mg} / l$ になるよう粒状活性炭沪過して THM ゃ 前駆物質を除去した水道水で調整したものを用いた。な お，この人工下水の TOC は $180 \mathrm{mg} / l, \mathrm{BOD}$ は 210 $\mathrm{mg} / \mathrm{l}$ である. この人工下水を定量ポンプでTable 1 に なるよう供給し，有機物負荷を変化させる処理実験を 行った.

処理水とその沃液 $(0.45 \mu \mathrm{m})$, および嚗気槽混合液 を試料とし，SS，TOC，前駆物質および污泥の濁質除 去能 (Biological Adsorption Capacity 以下 BAC とす る) 等を測定した.

前駆物質濃度は次のようにして求めた。試料の TOC が約 $5 \mathrm{mg} / l$ になるように希积調整し， 24 時間後の遊離 残留塩素濃度が約 $5 \mathrm{mg} / l$ になるように塩素を添加し， $\mathrm{pH} 7$, 温度 $20^{\circ} \mathrm{C}$ で塩素と反応させる. 24 時間後に生成 している THM 濃度を測定し，これを試料水の前駆物 質濃度（以下 THMFP とする）とした。なお，THM は常法 ${ }^{6}$ により測定した.

また，BACは次のようにして求めた，曝気槽混合液 $200 \mathrm{~m} l$ を遠心分離し, 沈殿物をビーカーに移し,これ に人工下水と同じ組成の無機塩溶液を加えて摫汼し，30

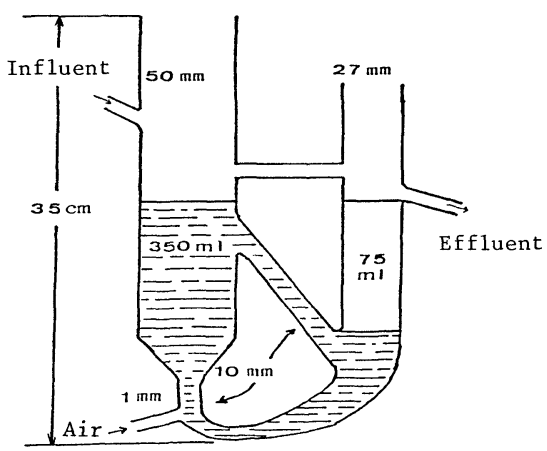

Fig. 1 Bench scale activated sludge reactor.
分静止後上澄水を捨てる. 次に人工下水 $200 \mathrm{~m} l$ を加え ジャーテスターで $150 \mathrm{rpm}, 30$ 分間覧汼し, 静置後上澄 水の濁度を測定する．また，同一䚋拌条件で無機塩溶液 を加え靦汼, 静置したときの上澄水の濁度を求め, 上記 の濁度との差を MLSS で除した値を BAC とした.

\section{（2）都市下水を基質とする実験}

家庭下水の占める割合が高い下水処理場（処理水量 40 万 $\mathrm{m}^{3}$ /日・ステップエアレーション法）最初沈殿池 流出水および最終沈殿池流出水の THM 生成特性を把 握するための調査, およびその最初沈殿池流出水を基質 とする活性污泥処理実験を行った．それらの実験方法は 次のようである.

下水処理場最初沈殿池流出水 (以下一次処理水亡する) および最終沈殿池流出水（以下二次処理水とする）を採 取し，これを，ふるいおよびメンブレンフィルターによ り分画して分画試料を調整し, 各分画試料について THMFP およびTOC を測定した.

活性污泥による処理実験は人工下水の実験に用いたも のと同じ装置を用いて行った. 原水は最初沈殿池流出水 中の夾雑物を $0.5 \mathrm{~mm}$ のふるいで除去したもの（以下 T 下水とする) およびこれを $8 \mu \mathrm{m}$ のメンブレンフィル ターで沪過したもの（以下F下水とする）をそれぞれ 用いた。活性污泥に対する有機物負荷は嚗気槽混合液の 一定量を 1 日 1 回引き抜いて活性污泥の懪気槽内平均滞 留時間 (以下 $\theta_{c}$ 值とする) を変化させて調整した．そ の実験条件を Table 2 に示す．なお $\theta_{c}$ 值は系内全活性 污泥量を 1 日当たりの引抜き污泥量と流出水 $\mathrm{SS}$ 量の和 で除したものである.

本実験では, THMFP とともに全有機ハロゲン化合 物前駆物質 (TOXFP) も測定した。すなわち, THMFP 測定と同様に試料を塩素処理し，反応終了時 に生成している全有機ハロゲン化合物を TOX 計を用い て分析し，この TOX 量をもって TOXFP とした.

また，処理水について常法によりセファデックスゲル G-25 を用いたゲルクロマトグラフィーを行い, 溶解性 有機物の分子量分画を行った.

このほか, BOD, COD, TOC, SS, 紫外部吸光度, 色度を測定したが，これらの測定法も常法によった。

\section{3. 結果および考察}

\section{（1）人工下水を基質とする実験}

人工下水を原水とする活性污泥処理実験の各実験条件 の定常状態における有機物負荷およびTOC 除去率も Table 1 に示した。本実験では余㮃污泥を引き抜いて活 性污泥濃度を一定に保持するようにしなかったので，曝 気槽滞留時間 (Aeration-tank Retention Time以下 ART とする）の設定幅ほど有機物負荷の範囲は広くと 
Table 1 Operational conditions of the activated sludge reactor and TOC reduction.

\begin{tabular}{cccccc}
\hline Run No. & $\begin{array}{c}\text { Flow Rate } \\
(1 / \text { day })\end{array}$ & \multicolumn{2}{c}{ BOD Loading $(1 /$ day $)$} & $\begin{array}{c}\text { Retention } \\
\text { Time }(\mathrm{hr})\end{array}$ & $\begin{array}{c}\text { TOC Reduction } \\
(\%)\end{array}$ \\
\cline { 3 - 5 } & Volume $(\mathrm{g} / 1)$ & SS $(\mathrm{g} / \mathrm{g})$ & & \\
\hline 1 & 0.50 & 0.20 & 0.10 & 20.3 & 93.4 \\
2 & 0.89 & 0.54 & 0.14 & 11.4 & 92.9 \\
3 & 1.22 & 0.74 & 0.16 & 8.3 & 91.0 \\
4 & 2.40 & 1.44 & 0.20 & 4.3 & 90.8 \\
\hline
\end{tabular}

れなかったものの, Fig. 2 に示すようにMLSS および $\mathrm{BAC}$ は ART により大きく変化していた。

有機物負荷の高い条件下で生成する活性污泥，すなわ ち污泥令が短い活性污泥ほよ゙その凝集性が低いことを真 柄ら ${ }^{4)}$ は報告しており，本実験においても ART が短い 条件ほど BAC 值は小さくなる傾向が認められた．特に 最も ART が短い条件下での活性污泥では, 活性污泥に 吸着していた澱粉が脱着したため BAC 值は負の值を示 した.これらの結果より, ART は活性污泥の懸濁性有 機物に対する仮想的な凝集・吸着部位の存在量とも関係 しており，その凝集・吸着部位は活性污泥の污泥令ある

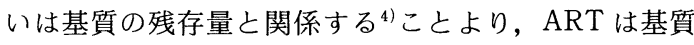
として加えた澱粉が生物化学的に可溶化され活性污泥と して転換されていく代謝時間のパラメーターとして扱い 得るものと考える.

処理水を塩素処理した結果，すべての処理水が THM を生成した。実験に用いた基質は THM を生成しない 有機物であることから，活性污泥の代謝作用によって THM を生成しない有機物から THM を生成する有機物 が生成されることとなる. ARTと処理水およびその沪 液の TOC, THMFP, THMFP/TOC（以下 THM 生 成率とする）の関係について Fig. 3 にそれぞれ示す.

TOC の除去率は ART が長くなるほど高くなる傾向 が認められるが，いずれの条件でも $90 \%$ 以上と高い除 去率を示した。しかし, THMFP, THM 生成率とも ART により大きく変化している. 処理水未洰液では, ART が短いほどTHMFP が高くなり，またTHMFP が最小となるART が存在している.これは処理水中に

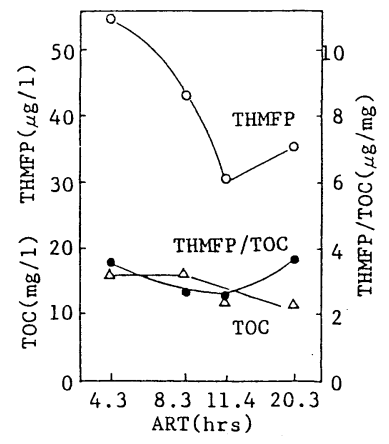

(a) effluent

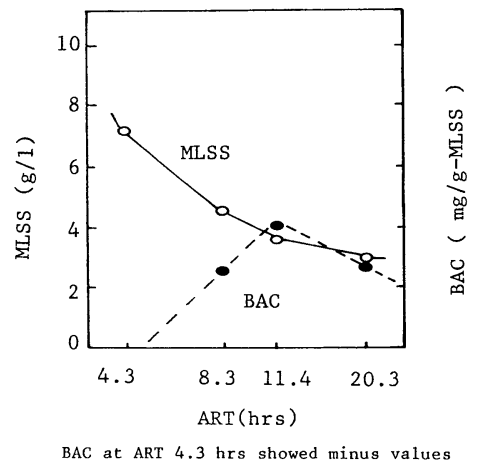

Fig. 2 Relationship between ART and MLSS, and BAC.

流出した活性污泥の THMFP の影響を受けているため である.すなわち，未沦水と沪過水の TOC の差は活性 污泥の TOCであり, ART が短い条件では約 $10 \mathrm{mg} / l$ の TOC に相当する活性污泥が流出している. ART が 短い条件下での活性污泥の流出量が多い理由としては, MLSS 濃度が高いため沈殿槽の容量が不足したことと $\mathrm{BAC}$ 值が低いことが示すように活性污泥の凝集・フ ロック形成能が低かったためであろうと思われる.これ らの差から単位活性污泥当たりの THM 生成率を求め るとART が短い条件では約 $1.6 \sim 3.1 \mu \mathrm{g} / \mathrm{mg}$ TOC で あった. したがって, 活性污泥法処理水の THMFP の 制御には MLSS の流出を少なくすることが効果がある ものと思われる. また，処理水中の THMFP が最小に なる ART は BAC 值が極大を示す ARTでもあること は, 活性污泥法の凝集・吸着性を支配し, 有機物除去性 を支配する污泥令が処理水の THMFP とも関係してい ることを示唆しているものと考えられる.

処理水沪過液では，ART が長くなるほど THM 生成 率が高い.この処理水を G-25 セファデックスゲルを用 いて $\mathrm{Kd}$ 値が $0.0 \sim 0.34$ (G I ), 0.37〜0.56 (G II ), $0.60 \sim 1.0$ (G III ) の三群に分画し, 各画群の THM 生 成率を求めた結果を示すと Fig. 4 のようであり, 高分子

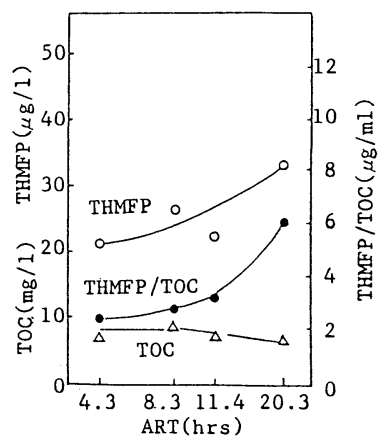

(b) $0.45 \mu \mathrm{m}$ filtrate of effluent

Fig. 3 Relationship between ART and THMFP, and THMFP/TOC of the effluent. 
量の溶解性有機物の THM 生成率はART に関係なくほ ぼ一定であるが低分子量の溶解性有機物のそれはART が長くなると天然の植物由来のフミン質と同じ程度の THM 生成率 ${ }^{7)}$ となることが明らかとなった。これらの ことより，基質とした澱粉が可溶化した有機物は THMFP が低く，さらに分解されて低分子の活性污泥 の代謝排物として存在するようにまでなると THMFP が高くなるものと考えられる．したがって，Fig. 3 に示 す沃過液の THMFP とART の関係は，ART の短い条 件下では澱粉の可溶化した有機物で THM を生成しな い有機物の占める割合が高く, ART が長くなれば天然 の植物由来のフミン質と類似した有機物の占める割合が 高くなることを意味しているものと考えられる.

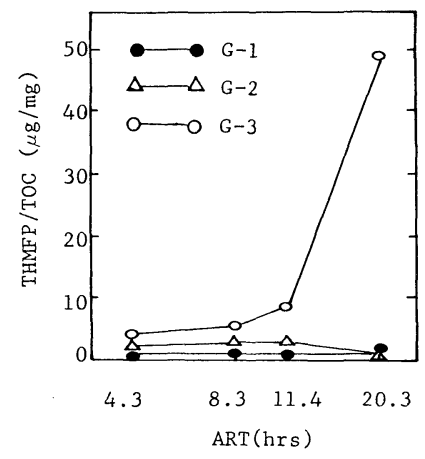

Fig. 4 Relationship between ART and THMFP/TOC of fractionated components.

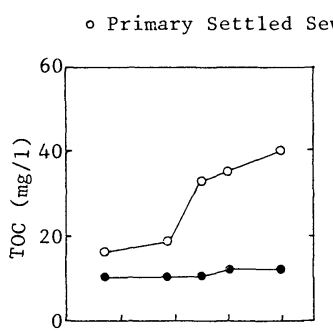

$\begin{array}{lllll}.1 & 1 & 10 & 100 & 1000\end{array}$

Pàticle size $(\mu \mathrm{m})$

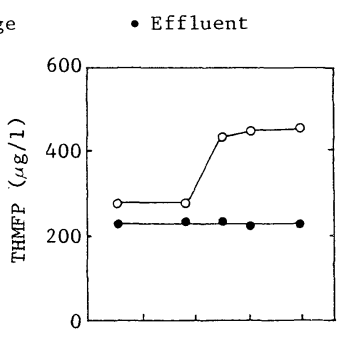

$\begin{array}{lllll}.1 & 1 & 10 & 100 & 1000\end{array}$ Particle size $(\mu \mathrm{m})$
Fig. 5 Relationship between particle size and TOC, and THMFP.

Table 2 The experimental conditions of the activated sludge reactors fed by primary settled municipal sewage and its filtrate of $8 \mu \mathrm{m}$ filter.

\begin{tabular}{|c|c|c|c|c|c|c|}
\hline \multirow[b]{2}{*}{$\begin{array}{c}\theta c \\
\text { (day) }\end{array}$} & \multicolumn{3}{|c|}{$\mathrm{T}$ series } & \multicolumn{3}{|c|}{ F series } \\
\hline & Run No. & $\begin{array}{c}\text { BOD Loading } \\
(\mathrm{g} / \mathrm{g} \text {-day })\end{array}$ & $\begin{array}{l}\text { MLSS } \\
(\mathrm{mg} / 1)\end{array}$ & Run No. & $\begin{array}{l}\text { BOD Loading } \\
\text { (g/g-day) }\end{array}$ & $\begin{array}{l}\text { MLSS } \\
(\mathrm{mg} / 1)\end{array}$ \\
\hline 16 & 5 & 0.15 & $2543 \pm 249$ & 9 & 0.23 & $805 \pm 159$ \\
\hline 9 & 6 & 0.20 & $1836 \pm 279$ & 10 & 0.32 & $580 \pm 91$ \\
\hline 6 & 7 & 0.30 & $1258 \pm 284$ & 11 & 0.52 & $355 \pm 57$ \\
\hline 4 & 8 & 0.44 & $848 \pm 94$ & 12 & 0.71 & $258 \pm 47$ \\
\hline
\end{tabular}

\section{（2）都市下水処理場での調查}

家庭下水の占める割合が高い下水処理場の一次処理水 之二次処理水をそれぞれふるいおよびメンブレンフィル ターで沪過し，各沃液の TOC および THMFP を測定 した結果を Fig. 5 に示す。一次処理水の TOC は約 40 $\mathrm{mg} / l$ であり，そのうち $0.45 \mu \mathrm{m}$ 以下すなわち溶解性有 機物は全体の $40 \%$ を占めるにすぎない. 二次処理水の TOC は約 $12 \mathrm{mg} / l$ であるが， $95 \%$ 以上が溶解性有機 物である.したがって, TOC の除去率は $70 \%$ であるが， 懸濁性有機物の除去率は $92 \%$, 溶解性有機物のそれは $38 \%$ となり，活性污泥法処理は見掛け上懸濁物質の除 去が卓越していることになる.

一次処理水の THMFP は約 $460 \mu \mathrm{g} / l$ であり，そのう ち溶解性 THMFP は $270 \mu \mathrm{g} / l$ と $60 \%$ を占める. 二次 処理水の THMFP は $230 \mu \mathrm{g} / l$ であり, 活性污泥法処理 の THMFP 除去率は TOC 除去率に比べて低い $50 \%$ であり，しかもFig. 5 に示すように見掛け上懸濁性 THMFP のみが除去されるため溶解性 THMFP の除去 率はきわめて低いということになる.これらのことより， 都市下水を処理する活性污泥法では，THM を生成しな い有機物が選択的に除去されるか，あるいは有機物が活 性污泥の代謝作用により THM を生成しやすい溶解性 有機物の占める割合が高くなるものと考えられる．特に 一次処理水の $\mathrm{THM}$ 生成率が約 $10 \mathrm{mg} / \mathrm{g}$ であるのに対 して二次処理水のそれは約 $20 \mathrm{mg} / \mathrm{g}$ にまで増加してい ることからも, 有機物の特性が変化しているものと考え られる.

\section{（3）都市下水を基質とする実験}

前節で調查を行った処理場の一次処理水を採取し,こ れを前章に記した方法によって調整した下水を原水とす る活性污泥処理実験の各実験条件の定常状態における有 機物負荷および MLSS 濃度も Table 2 に示す。また， 各実験条件の原水および処理水の BOD 等一般水質項目 の平均値を Table 3 に示す.

Table 3 General characteristics of the influent and the effluent.

\begin{tabular}{cccccc}
\hline $\begin{array}{c}\text { Series/ } \\
\text { Run No. }\end{array}$ & $\begin{array}{c}\text { BOD } \\
(\mathrm{mg} / 1)\end{array}$ & $\begin{array}{c}\text { COD } \\
(\mathrm{mg} / 1)\end{array}$ & $\begin{array}{c}\text { TOC } \\
(\mathrm{mg} / 1)\end{array}$ & $\begin{array}{c}\mathrm{SS} \\
(\mathrm{mg} / 1)\end{array}$ & $\mathrm{pH}$ \\
\hline $\mathrm{T}$ & 110 & 50 & 74 & 89 & 7.2 \\
$\mathrm{~F}$ & 54 & 32 & 49 & 25 & 7.2 \\
\hline 5 & 2.5 & 14.2 & 14.3 & 25 & 6.0 \\
6 & 2.5 & 14.6 & 14.6 & 19 & 6.2 \\
7 & 2.6 & 15.9 & 15.5 & 14 & 6.6 \\
8 & 3.8 & 16.2 & 14.3 & 14 & 7.0 \\
\hline 9 & 2.4 & 16.0 & 13.4 & 12 & 6.5 \\
10 & 2.6 & 14.6 & 14.1 & 10 & 6.6 \\
11 & 3.2 & 15.1 & 14.1 & 10 & 7.0 \\
12 & 4.4 & 17.1 & 14.6 & 9 & 7.1 \\
\hline
\end{tabular}

$T, F$ : Influent 5-12: Effluent 
懸濁性有機物を含む T 下水を原水とする Run 5 8 の 有機物負荷は 0.15 0. $44 \mathrm{kgBOD} / \mathrm{kgSS}$ ・日と活性污泥 法の一般的な有機物負荷の範囲にあった。一方， $8 \mu \mathrm{m}$ のフィルターで沪過したため Table 3 に示すようにSS が残存しているが, 溶解性有機物の占める割合が高い F 下水を原水とする Run 9 12では有機物負荷は 0.23 $\sim 0.71 \mathrm{kgBOD} / \mathrm{kgSS}$ ・日と T 下水の系列に比べて高い 值となった。これは, F下水系列の活性污泥は主とし て溶解性有機物を基質として増殖したものであり, MLSS が Table 2 に示すように低い值にしか保持でき なかったためである. しかし，処理水の水質はいずれの 系列も同程度であり，しかも活性污泥法の限界水質に近 い値を示していることから, 本実験は都市下水を処理す る活性污泥法としては良好な処理条件を設定していたも のと思われる.

実験条件の指標とした $\theta_{c}$ 值は活性污泥の比増殖速度 の逆数であるので, 処理水中の基質濃度を規定すること になる ${ }^{8)}$. Table 3に示すように, 本実験結果でも活性 污泥微生物が代謝可能な有機物量の指標之扱い得る BOD については $\theta_{c}$ 值が小さくなるほど大きな值となっ ている. しかし, その他の水質項目については $\theta_{c}$ 值と の間に BOD ほど明らかな傾向は認められない。これは, 処理水中に残存する有機物が, 原水中の基質で活性污泥 に利用されないまま残存したいたものと, 活性污泥の代 謝排物で微生物に分解されにくい有機物とから構成され ているためと思われる.

Run 5 12の原水について, TOC おょび色度と TOXFP との関係を Fig. 6 に示すが, TOXFP はTOC および色度と高い相関があり, 都市下水の TOXFPは その TOC あるいは色度をもって推定することが可能で あるものと考えられる.

各実験条件における原水および処理水の有機ハロゲン 化合物の前駆物質について生成量および生成率を Fig. 7 に示す．懸濁性有機物を含む原水を処理したRun $5 \sim 8$ (T 系列) の処理水の THMFP は $\theta_{c}$ 值にもかかわらず
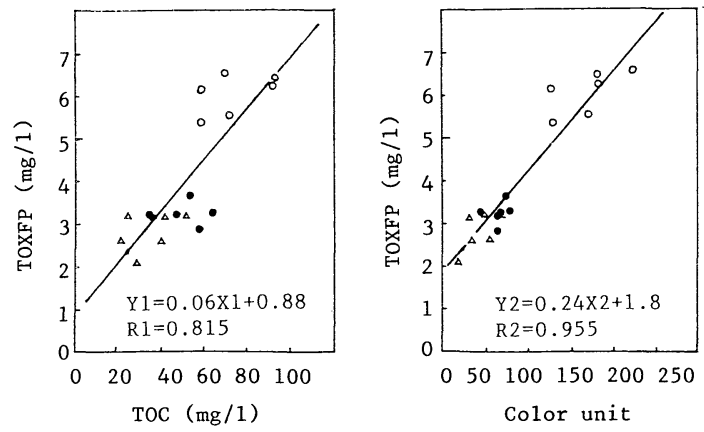

Fig. 6 Relationship between TOXFP and TOC, and color unit.
約 $170 \mu \mathrm{g} / l$ でほぼ一定の值を示し, その除去率は約 35 $\%$ と下水処理場での調査で得られた約 $50 \%$ より若干低 い值であった。

懸濁性有機物を除去した原水を処理したRun 9 12 (F 系列) の処理水の THMFP は $\theta_{c}$ 值が大きくなるに つれて高くなる傾向がみられ，その除去率はRun 9 で 約 $35 \%$, Run 12 で約 $20 \%$ であった. THM 生成率に ついては，いずれの実験でも原水に比べて処理水の方が 高い値となっており, 人工下水での実験結果や処理場の 調査結果と同じ傾向が認められる.

本実験条件の原水および処理水について，それぞれの 平均值を求めると Table 4 に示すとおりである. いずれ の実験でも処理水の TOXFP は約 $1350 \mu \mathrm{g} / l$ であり, $\theta_{c}$ 值あるいは䯚濁性有機物の有無による差は認められ ない. しかし除去率ではRun 5 R が約 $80 \%$ とRun 9 ～12 の約 $60 \%$ に比べて高く, 懸濁性有機物起因による

$$
\text { - } \mathrm{T} \text { series } \quad \mathrm{F} \text { series }
$$
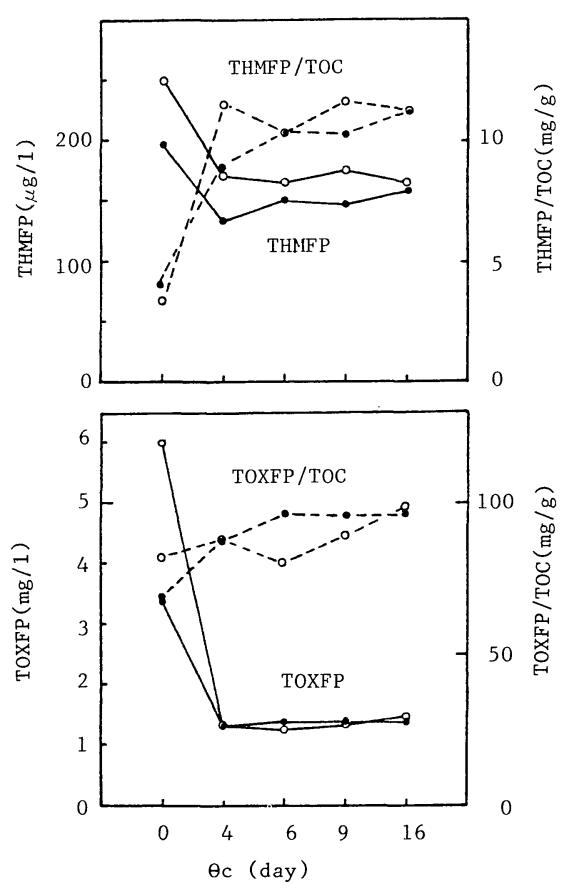

$\theta c=0:$ Influent

Fig. 7 Relationship between $\theta_{c}$ and THM \& TOXFP of the influent and the effluent.

Table 4 Average THMFP and TOXFP of the influent and the effluent.

\begin{tabular}{ccccccc}
\hline & Series & $\begin{array}{c}\text { THMFP } \\
(\mu \mathrm{g} / \mathrm{l})\end{array}$ & $\begin{array}{c}\text { TOXFP } \\
(\mu \mathrm{g} / \mathrm{l})\end{array}$ & $\begin{array}{c}\text { THMFP/TOC } \\
(\mathrm{mg} / \mathrm{g})\end{array}$ & $\begin{array}{c}\text { TOXFP/TOC } \\
(\mathrm{mg} / \mathrm{g})\end{array}$ & $\begin{array}{c}\text { THMFP/TOXFP } \\
(\%)\end{array}$ \\
\hline \multirow{2}{*}{ Influent } & $\mathrm{T}$ & 250 & 6030 & 3.33 & 81.5 & 4.1 \\
& $\mathrm{~F}$ & 196 & 3380 & 4.00 & 69.0 & 5.8 \\
\hline \multirow{2}{*}{ Effluent } & $\mathrm{T}$ & 169 & 1340 & 11.6 & 92.5 & 12.6 \\
& $\mathrm{~F}$ & 147 & 1360 & 10.5 & 96.9 & 10.8 \\
\hline
\end{tabular}


TOXFP はほぼ完全に除去されていると思われる結果 が得られた。

TOX 生成率は THM 生成率と同様に, 処理水の方が 原水より高くなっている. しかし，処理水の原水に対す るそれぞれの増加した比率は THM 生成率で約 3.5 倍, TOX 生成率で約 1.1 倍である. また原水中の THMFP の TOXFP に占める割合は平均 $4.1 \%$ であるが, 処理 水では平均 $12.6 \%$ と増加している.これらのことから も, 活性污泥は見掛け上 TOXFP を除去する能力は高 いものの THMFP を除去する能力は低いものと考えら れる.

原水および処理水の $0.45 \mu \mathrm{m}$ メンブレンフィルター 沪過液についてセファデックス G-25によるゲル沪過を 行ったところ, TOC, その他の水質項目についてはど の実験結果でも同じようなパターンであったのでその一 例をFig. 8 に示す. また, 原水およびRun 6, 10 の処 理水の各画群ごとの TOXFP に対する THMFP の割合 をTable 5 に示す．低分子画分である Kd 0.6 1.0 の G IIIIは原水中の Br イオンが分取される. 相沢ら ${ }^{9)}$ は有 機物と塩素が反応する系に Br イオンが共存すると, 生 成する THMFP は共存しない系に比べて多くなること があると報告しているので， G III の THMFP や TOXFP はBr イオンの影響を受けており, 他の画群の それと同一には比較できない. しかし, 活性污泥法処理 によっても Br イオン濃度は変化しないので, 処理前後 の各画群ごとの THMFP と TOXFP について比較する ことができる.すなわち，各画群でも先に記したように

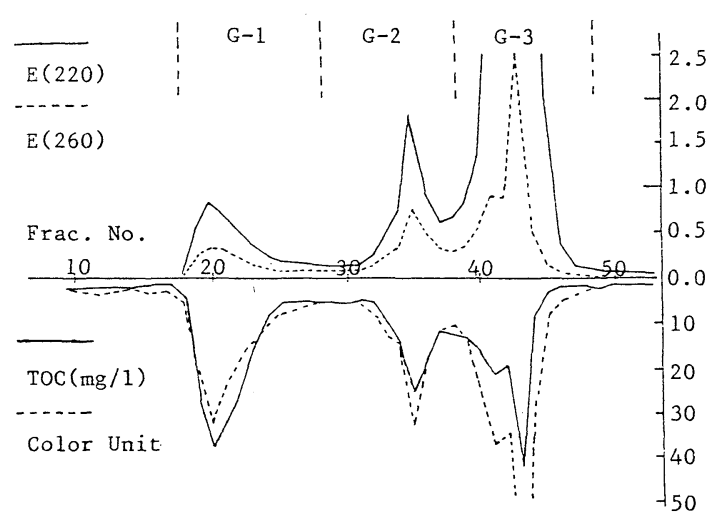

Fig. 8 Gel chromatogram of run 6 effluent.

Table 5 The ratios of THMFP/TOXFP of fractionated components $(\%)$.

\begin{tabular}{ccrr}
\hline & Influent & \multicolumn{2}{c}{ Effluent } \\
\cline { 3 - 4 } & & \multicolumn{1}{c}{ Run 6 } & Run 10 \\
\hline G-1 & 1.90 & 7.3 & 6.7 \\
G-2 & 1.25 & 8.6 & 8.4 \\
G-3 & 5.10 & 11.2 & 11.7 \\
\hline
\end{tabular}

TOC, TOXFP の除去率に比べ THMFP の除去率が低 く, その結果 THMFP/TOXFP の比率が高くなってい る. 相沢ら ${ }^{10)}$ は TOXFP は高いが THM を生成しない かあるいはその生成量が少ない有機物は, 脂肪族のアル デヒド類やカルボン酸および芳香族のベンゼンと不活性 基をもつベンゼンモノ置換体であると報告しており，ま たこれらの有機物は生物分解性の指標として有効である というオクタノール分配係数も高いので, 下水中の有機 物組成と活性污泥の有機物除去特性からこのような結果 が得られたものと思われる. しかし，澱粉を基質とした 実験で明らかにしたように, 活性污泥微生物の代謝に よって THM を生成するフミン質類似物質も同時に生 成されていることも事実である．したがって，原水の有 機物組成と活性污泥微生物の代謝廃物のいずれが処理水 の THMFP や TOXFP を規定しているかは, 本実験で は明らかにはできないので，このことについてはさらに 詳細な実験が要求されるものと考えられる.

曝気槽混合溶液およびそのメンブレンフィルター沪過 液の THMFP およびTOXFP を測定し，それぞれの差 より活性污泥の THMFP および TOXFP を求め, それ ぞれを MLSS で除して単位 MLSS 当たりの THMFP およびTOXFPを求めた結果を示すと Fig. 9 のように なる．すなわち， $\theta_{c}$ 值が変化してもこれらの值は変化 せず，いずれの系列でも THMFP/ MLSS が 0.84 $\mu \mathrm{g} / \mathrm{mg}$, TOXFP/MLSS が $30.4 \mu \mathrm{g} / \mathrm{mg}$ であり, 宗宮 $ら^{1), 2)}$ の報告した值とほぼ一致した結果が得られた。こ の実験条件の処理水 BOD は低く活性污泥法処理の限界 条件に近いため, 処理水の有機物は微生物に分解されな い有機物，すなわち天然のフミン質に類似した有機物の 占める割合が高くなったため $\theta_{c}$ 值の影響を受けなかっ たためと思われる. 原水について単位 SS 当たりの THMFP を求めると $0.67 \mu \mathrm{g} / \mathrm{mg}$ であり, 懪気槽内の SS すなわち活性污泥より低い值を示しており, 活性污
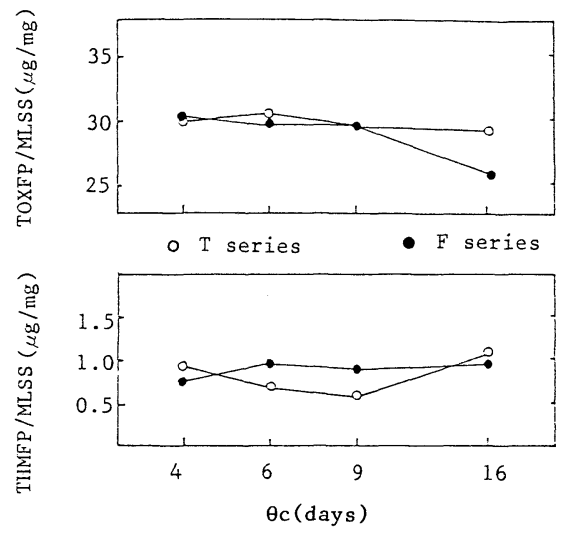

Fig. 9 Relationship between $\theta_{c}$ and THMFP/MLSS, and TOXFP/MLSS. 
泥中にも原水に比べて THM を生成するような代謝物 質の占める割合が高くなっていたと思われる.

Table 4 に示すように原水中の懸濁性の有機物質に起 因する $\mathrm{THMFP}$ は $\mathrm{T}$ 原水と $\mathrm{F}$ 原水の $\mathrm{THMFP}$ の差 54 $\mu \mathrm{g} / l$ であり, 原水中の懸濁性の有機物質が活性污泥微 生物の反応を受けて生成した物質に起因する THMFP は $\mathrm{T}$ 系列処理水之 $\mathrm{F}$ 系列処理水の $\mathrm{THMFP} の$ 差 22 $\mu \mathrm{g} / l$ である. したがって, 懸濁性の有機物質に起因す る THMFP の除去率を求めると $59 \%$ となり，溶解性 有機物についてのその除去率 $25 \%$ に比べて高い值と なった。これは処理場における結果とも一致し，活性污 泥法は䯚濁性有機物質の THMFP を除去する機能は有 しているものの, 溶解性有機物の THMFP を除去する 機能は低いことが明らかである.

\section{4. おわりに}

澱粉を基質とする活性污泥法処理実験，下水処理場の 調查および都市下水を基質とする活性污泥法処理実験で 得られた結果をまとめると次のようになる.

活性污泥法では THM あるいは TOX を生成しない有 機物を活性污泥微生物が代謝する過程で THM や TOX を生成する有機物，すなわち前駆物質が生成される。 そ れらは活性污泥自体にも処理水自体にも存在し, その生 成量は活性污泥に対する有機物負荷が小さいほどすなわ ち污泥令が長いほど多くなる傾向がある.

都市下水中の有機ハロゲン化合物の前駆物質は, 懸濁 性物質之溶解性物質から成っており, 活性污泥法は懸濁 性前駆物質を除去する機能は高いものの溶解性前駆物質 を除去する機能は低い。しかし, 活性污泥はTHM や TOX を生成しない BOD で示されるような微生物分解 性の有機物質の除去能はきわめて高い。したがって処理 水中には THM や TOX を生成しやすく, 微生物には分 解されにくい有機物が残存するとともに, 活性污泥が生 物分解性有機物を代謝する過程で前駆物質を排出するの で，処理水中には前駆物質の占める割合が高く, TOC 当たりの THM あるいは TOX 生成量も高くなる，すな わち, 原水より処理水の $\mathrm{THM}$ 生成率あるいは $\mathrm{TOX}$ 生 成率は高くなる.

活性污泥の THM 前駆物質除去性と TOX 前駆物質除 去性とを比べると TOX 前駆物質の除去性が高い。この 理由としては TOX 前駆物質が THM 前駆物質に比べて 一般に親水性が強いため生分解性が高いためと考えられ るが, 今後の検討課題としたい.

活性污泥法処理水中の溶解性有機物質の THM 生成 率は, 原水中の生物分解性有機物の除去がほぼ限界と思 われる条件下でも約 $10 \mu \mathrm{g} / \mathrm{mgTOC}$ である。，一方，下 水中の懸濁性有機物や活性污泥自体も単位 SS (mg) 当
たり約 $1 \mu \mathrm{g}$ の THM を生成する．標準的な活性污泥法 処理は，曝気槽滞留時間や污泥令が最も短い状態で最大 の BOD 除去率と処理水 SS を最小にするよう設計や運 転がなされている。これは活性污泥の処理水への流出を 少なくする条件であるから，活性污泥法における THM および TOX 前駆物質を除去するための最も効率の高い 限界条件に近いものと考えられる. しかし，積極的に処 理水中の前駆物質を低減化しようとする場合には，污泥 処理工程特に消化プロセスを有する污泥処理工程からの 返送水には生物の代謝排物すなわち前駆物質が多量に存 在することになるので, 下水処理工程と污泥処理工程を 分離することや，標準活性污泥法の機能を補完する物理 化学的処理を後置することを検討する必要があるものと 考えられる。

本研究を行うにあたり, 適切なご指導と多大な援助を 賜った都立大学工学部川口士郎教授ならびに国立公害 研究所合田 健部長には心から御礼申し上げます。

\section{参 考 文 献}

1）山田春美・宗宮 功：活性污泥法終末処理場における有 機ハロゲン化合物前駆物質および低沸点有機ハロゲン化 合物の挙動, 水質污濁研究, Vol. 7, No. 4, pp. 239 248, 1984.

2）山田春美・宗宮 功：活性污泥に係わる有機塩素系化合 物前駆物質量, 水質污溞研究, Vol. 8, No. 4, pp. 223 232, 1985.

3) Koczwara, M.K. et al. : Formation of organic chlorine in activated sludge effluent, W.R., Vol.17, No.12, pp. 1863 1869, 1983.

4）真柄泰基・南部䍧一：活性污泥の沈降性を支配する生物 化学的因子に関する研究, 下水道協会誌, Vol. 11, No. 126, pp. 5 11, 1974.

5）丹保憲二・亀井 翼 : 生物分解性有機物の代謝にともな う低沸点有機塩素化合物前駆物質の生成, 土木学会衛生 工学委員会, 「低沸点有機塩素化合物の生成要因物質の制 御に関する研究」報告書, 1983 .

6)厚生省水道環境部水道整備課 : 水道における総トリハ口 メ夕ン 対策, 水道協会誌, No. 561, pp. $76 \sim 85$, S. 56. 6 .

7）相沢貴子・真柄泰基：トリハロメタン生成特性からみた 水質評価一天然有機着色水一, 水質污濁研究, Vol. 3, No. 4, pp.199 206, 1980.

8) Michael Saunders, F. and Dick, R. I. : Effect of mean cell residence time on organic composition of activated sludge effluents, J. WPCF, Vol.53, No.2, pp.201 215,1981

9）相沢貴子・鈴木信司・真柄泰基：トリハロメタン生成に 及ぼす臭素イオンの影響, 第 18 回衛生工学研究討論会講 演集, pp. 247〜252, 1982.

10）相沢貴子・長谷川一夫 - 足立幸子 - 真柄泰基 : 塩素処理 による有機化合物の全有機塩素化合物 $(\mathrm{TOCl})$ 生成特性, 水質污濁研究, Vol. 7, No. 2, pp. 36 45, 1984.

(1985.6.14 • 受付) 